\title{
Onze zorgers vallen om
}

I $\mathrm{k}$ lees de krant: 'Het grootste verloop van zorgpersoneel, sinds vijf jaar. En het hoogste verzuim'. ${ }^{1}$ 'Thuiszorg zet kantoorpersoneel in.' 'Docenten willen staken met verpleegkundigen'. ${ }^{3}$ Ik wil het eigenlijk niet steeds hebben over werkdruk in de zorg, want wat heeft het voor zin? Wie onderneemt er actie, terwijl ik mezelf herhaal? Iedereen die dit leest, kijkt om zich heen en vergeet zijn eigen keuzes, actie, kracht. Aan de andere kant... heb ik niet hier een hoekje in Nursing om de geluiden te vertellen van de werkvloer? Van de verpleegkundigen?

Nou, ik spreek er zo één in opleiding. Ze is fantastisch flexibel, creatief, leergierig. Ze verdiept zich in zaken die eigenlijk ver boven haar pet gaan, maar ze grijpt ze tot ze ze begrijpt. Ze houdt van haar vak, vertelt ze. Daarom evalueert ze in eigen tijd patiëntendossiers. Ze leest vakliteratuur, protocollen en managementstukken. Ik sla elke keer weer steil achterover van haar.

Vorige week echter was zij het die achterover sloeg. Niet omdat iets haar positief verraste. Nee. Omdat ze vorige week 45 uur werkte. Ondertussen begon ze te hoesten en werd ze schor. Maar haar collega's waren ziek. Ze moest wel door. Ondertussen bereidde ze haar examengesprek voor. Bijna klaar, bijna verpleegkundige. De werkvloer zag ook haar kwaliteiten en bijna-behaalde diploma en bood haar alvast een seniorfunctie aan. Voorafgaand aan haar examengesprek vertelt ze trots over haar vloedgolf extra verantwoordelijkheden. Mooi hoe haar kwaliteiten worden gezien (of grijpen zorgmanagers zich ook maar vast aan alles wat blijft drijven?) Maar moet een beginnend beroepsbeoefenaar niet eerst leren ademen, routine opbouwen, rust en haar eigen rol vinden, voor ze doorstoomt naar macroniveau? En heeft de directe beddenzorg (microniveau) haar ook niet heel hard nodig met haar gretigheid, tonnen energie en verse kennis? Zo snel als haar carrière vordert, zo snel groeit ook haar pneumonie. Door alle magie in haar lijf in één keer in te zetten (werkverantwoordelijkheden, schoolprestaties, thuisfront), loopt haar verkoud- en vermoeidheid volledig uit de hand.

Zo komt ze bij mij met de vrijwel geluidloze mededeling: 'Ik doe wel dit gesprek, maar ik zie een beetje dubbel'. Het examengesprek begint. Ik merk dat haar focus ontbreekt. Wij trekken en duwen om haar te laten zeggen wat we willen horen, maar ze is te moe, denk ik. Ze haalt een onvoldoende.

Het weekend moet ze weer werken. Ondertussen bereidt ze in vrije tijd haar herexamengesprek voor. Ze werkt, hoest, leest en werkt weer. Tot ze midden onder de ADL stil blijft. Ze kijkt haar cliënt verontschuldigend aan en valt flauw.

Deze held van een senior-bijna-verpleegkundige ligt in het ziekenhuis, benauwd, grauw en bleek. De zorger is nu patiënt. Al haar inspiratie, energie, kennis en wilskracht is weg. Opgebruikt nog voor ze haar diploma kon halen.

Dat dus. Maar potverdorie, wie leest dit? Help! Onze zorgers vallen om!

Basisschooldocenten staken al een poos. Die voelen zich verantwoordelijk en angstig over hun arbeidsomstandigheden. Ze nodigen ons nu uit. Zij zien onze strijd. Wat gaan we doen?

\section{Noten}

1 www.nu.nl/economie/5445866/personeelsverloop-in-zorg-hoogste-niveau-in-vijf-jaar.html

2 https://nos.nl/artikel/2243249-wijkzorg-zetkantoorpersoneel-in-tegen-gaten-zomerroosters.html

3 www.nursing.nl/boze-leerkrachten-willen-actievoeren-met-verpleegkundigen/ 